\title{
NK-1 and NK-3 Type Tachykinin Receptor mRNA Expression in the Rat Spinal Cord Dorsal Horn Is Increased during Adjuvant or Formalin-induced Nociception
}

\author{
Kenneth E. McCarson and James E. Krause \\ Department of Anatomy and Neurobiology, Washington University School of Medicine, Saint Louis, Missouri 63110
}

Substance $P(S P)$ and other related tachykinins such as neurokinin $B$ (NKB) have been studied widely as mediators of sensory information. The release of SP into the dorsal horn of the spinal cord is increased during nociception, and SP activates nociception-specific dorsal horn neurons. The tachykinin NKB has antinociceptive effects in the spinal cord and is contained in intrinsic spinal neurons; thus, NKB may also contribute to the processing of sensory information. Both neurokinin-1 (NK-1) and neurokinin-3 (NK-3) receptors have been localized in the superficial laminae of the dorsal horn. This study investigated changes in NK-1 and NK-3 receptor mRNA expression during nociception. Following injection of either formalin or complete Freund's adjuvant (CFA) into one hindpaw, the levels of expression of NK-1 and NK-3 mRNAs in the spinal cord dorsal horn and preprotachykinin (PPT) mRNA expression in the lumbar dorsal root ganglia (DRG) were quantitated using solution hybridization-nuclease protection assays. Peptide and receptor mRNA expression levels were normalized to $\beta$-actin mRNA levels, which did not change during the treatments. Formalin ( 2 or $6 \mathrm{hr}$ ) or CFA (4 d) injection produced approximately a twofold increase in SP-encoding PPT mRNA expression in the ipsilateral lumbar DRG. Increased activity in primary afferent neurons containing SP may stimulate the production of SP precursors, providing substrate for increased SP production, release, and turnover in the dorsal horn and periphery. Formalin or CFA increased NK-1 receptor mRNA expression by about twofold in the ipsilateral dorsal horn. Activated SPcontaining primary afferent neurons may provide the neuronal drive for this increase. Formalin or CFA also increased NK-3 receptor mRNA expression by about twofold in the dorsal horn. Nociception may trigger increased activity of intrinsic NKB antinociceptive systems that could act to limit or modify transmission of nociceptive information to higher brain centers. These results provide evidence for activityinduced plasticity of tachykinin receptor expression in nociceptive sensory systems during subchronic nociceptive activation.

[Key words: substance $P$, neurokinin $B, N K-1$ receptor, NK-3 receptor, nociception, formalin test, adjuvant]

Received April 13, 1993; revised July 16, 1993; accepted July 22, 1993.

This work was supported by National Institutes of Health Grant NS21937. K.E.M. was supported by NRSA 54782 and NRSA 5-T32-NS0707.

Correspondence should be addressed to James E. Krause, Department of Anatomy and Neurobiology, Washington University School of Medicine, 660 South Euclid Avenue, Box 8108, St. Louis, MO 63110.

Copyright (C) 1994 Society for Neuroscience 0270-6474/94/140712-09\$05.00/0
The undecapeptide substance $\mathrm{P}(\mathrm{SP})$ and other tachykinin peptides such as neurokinin $\mathrm{B}$ (NKB) have been widely studied as mediators of sensory information in the nervous system. The tachykinins are a family of peptide neurotransmitters and/or neuromodulators that share a highly conserved carboxy-terminal amino acid sequence. The actions of SP in the spinal cord are widely accepted as being involved in nociception (Pernow, 1983; Otsuka and Yanagisawa, 1987). The release of SP into the spinal cord can be evoked by noxious stimulation of the periphery (Yaksh et al., 1980; Kuraishi et al., 1983; Oku et al., 1987; McCarson and Goldstein, 1991), and intrathecal injection of SP produces various pain-related behaviors (Doi and Jurna, 1981; Piercey et al., 1981; Hylden and Wilcox, 1983a,b; Matsumura et al., 1985). Afferent terminals containing SP have been shown to appose primarily nociception-specific dorsal horn neurons (DeKoninck ct al., 1992), and SP selectively activates dorsal horn cells that normally receive nociceptive afferent input (Henry, 1976).

Three different tachykinin receptors have been cloned and characterized. Each exhibits binding selectivity for one of the various tachykinins, and all show a similarity to other G-protein-coupled receptors (Nakanishi, 1991; Krause et al., 1993). In the spinal cord, two of these receptor sites have been implicated in sensory transmission. The neurokinin-1 receptor (NK-1 or SP receptor; Yokota et al., 1989; Hershey and Krause, 1990) has the highest affinity for SP of the tachykinin receptors. In the spinal cord, NK-1 sites are found primarily in the superficial dorsal horn (laminae I and II) in the region of termination of SP-containing primary afferent neurons (Yashpal et al., 1990; Moussaoui et al., 1992). The mechanism of action of SP at the NK-1 receptor involves phospholipase C-mediated phosphoinositol hydrolysis (Hanley et al., 1980; Hunter et al., 1985), which subsequently mobilizes internal $\mathrm{Ca}^{2+}$ stores (Streb et al., 1983) and activates protein kinase C (Kishimoto et al., 1980). The rate of phospholipid hydrolysis has been shown to be directly proportional to the number of SP binding sites in the rat CNS (Mantyh et al., 1984). The activation of nociception-specific dorsal horn neurons (Salter and Henry, 1991) and certain aspects of thermal and chemical nociception (Yamamoto and Yaksh, 1991; Yashpal et al., 1993) can be blocked by the nonpeptide NK-1 receptor antagonist CP-96,345. Thus, the NK-1 receptor appears to have an important role in the processing of nociceptive information in the dorsal horn, and regulation of NK-1 receptor expression may play an important role in the regulation of pain transmission. Less is known about the actions of NKB in the spinal cord. The majority of NKB in the dorsal horn is found in intrinsic spinal neurons (Ogawa et al., 1985), 
and NKB has been reported to have antinociceptive effects in the spinal cord (Laneuville et al., 1988). The neurokinin-3 (NK3) receptor (NKB receptor or neuromedin K receptor; Shigemoto et al., 1990) is found in the superficial dorsal horn (laminae I and II) of the spinal cord (Yashpal et al., 1990), and NKB has the highest affinity of the tachykinins for the NK-3 receptor (Helke et al., 1990). Thus, the primary role of NKB in the dorsal horn of the spinal cord could be related to the processing of afferent nociceptive information.

Two widely used animal models of subchronic nociception consist of the injection of formalin or complete Freund's adjuvant (CFA) into the plantar aspect of one hindpaw of a rat. The formalin test (Dubuisson and Dennis, 1977) produces a biphasic pain-related behavioral response within the first hour after injection into the hindpaw and an inflammation of the paw that is long lasting (Tjolsen et al., 1992). Formalin injection into the hindpaw has been shown to increase SP immunoreactivity in the dorsal horn (Kantner et al., 1985; McCarson and Goldstein, 1989, 1990) and increase the expression of SP-encoding preprotachykinin (PPT) mRNAs in the lumbar dorsal root ganglia (DRG) (Noguchi et al., 1988). Injection of CFA into one hindpaw produces a longer-lasting monoarthritic inflammation that peaks after about $4 \mathrm{~d}$ (Iadarola et al., 1988a,b). The use of CFA as a nociceptive activator has becn shown to potentiatc SP release into the dorsal horn of the spinal cord (Oku et al., 1987). CFA-induced nociception also increases the levels of SPencoding PPT mRNAs in the lumbar DRG and spinal cord dorsal horn (Minami et al., 1989; Donaldson et al., 1992).

Although much is known about the regulation of expression of the tachykinin peptides and their role in nociception, little is known about how nociceptive activation may alter tachykinin receptor expression or sensitivity, or the role that these receptors play in nociceptive processing. Further, the altered expression and/or release of tachykinin peptides may directly or indirectly affect tachykinin receptor function and expression during nociception. Therefore, this study was undertaken to determine the levels of NK-1 receptor (NK-1R) and NK-3 receptor (NK3R) mRNA expression in spinal cord regions and SP precursor (PPT) mRNA expression in the lumbar DRG following peripheral nociceptive activations.

\section{Materials and Methods}

Animals and nociceptive treatments. Twenty male Sprague-Dawley rats (250-300 gm; Harlan Sprague Dawley Inc., Indianapolis, IN) were used for this study. Ten rats received a subcutaneous injection of $100 \mu \mathrm{l}$ of $5 \%$ formalin (Sigma Chemical Co., St. Louis, MO) into the plantar aspect of the right hindpaw. Tissues were removed from five subjects $2 \mathrm{hr}$ after formalin injection; tissues were removed from the remaining five subjects $6 \mathrm{hr}$ after formalin injection. Five additional subjects received a subcutaneous injection of Freund's complete adjuvant $(50 \mu \mathrm{g} \mathrm{Myco-}$ bacterium butyricum in an oil-saline emulsion, $100 \mu 1$; Sigma) in the plantar aspect of the right hindpaw. Tissues were removed from these monoarthritic animals $4 \mathrm{~d}$ after CFA injection. In all cases, animals were visually monitored after injection to confirm inflammation of the hindpaw and for appearance of the appropriate pain-related hehaviors. Formalin-injected animals were observed during the $30 \mathrm{~min}$ immediately after treatment to confirm the appearance of both early and late phase bouts of pain-related behaviors (e.g., biting, licking, and lifting) directed toward the treated paw (Dubuisson and Dennis, 1977); CFAinjected animals were observed for appearance of pain-related behavior (guarding of the treated paw) within the first $60 \mathrm{~min}$ after treatment and periodically during the $4 \mathrm{~d}$ after treatment to confirm continued, profound inflammation of the injected paw (Iadarola et al., 1988b). Animals were housed individually in containers with excess bedding material with standard chow provided in the bedding to minimize discomfort during the treatment period. All animal procedures related to nociceptive treatments followed NIH guidelines and were reviewed and approved by the Washington University Institutional Animal Care and Use Committee. Five uninjected animals served as naive controls, resulting in four experimental groups with five subjects in each group. At the time of tissue removal, subjects were anesthetized with sodium pentobarbital (Vet Labs Ltd., Lenexa, KS; approximately $40 \mathrm{mg} / \mathrm{kg}$, i.p.). A laminectomy was then performed to expose the lumbar spinal cord and six lumbar DRGs (three DRGs, L4-L6, from each side). Tissues were quickly removed and frozen on dry ice. The spinal cord lumbar enlargements were dissected into longitudinal quarters along the sagittal midline and just above the central canal. The left and right side tissues were assayed separately, with the three DRGs from each side combined as one tissue sample. Animals were then killed with an overdose of sodium pentobarbital (approximately $150 \mathrm{mg} / \mathrm{kg}$, i.p.).

Isolation of total RNA. Total cellular RNAs were extracted from spinal cord and DRG tissue samples using a rapid guanidinium isothiocyanatephenol/chloroform extraction and subsequent precipitation with $0.3 \mathrm{M}$ sodium acetate and $75 \%$ ethanol (a modification of the method described by Chomczynski and Sacchi, 1987; unless otherwise stated, all reagents were of the highest purity available). The resulting RNA samples were subjected to spectrophotometric analysis and $5 \mu \mathrm{g}$ aliquots were electrophoresed on $1.5 \%$ agarose gels containing $6 \%$ formaldehyde to ensure integrity of each RNA preparation (Krause et al., 1987). One dorsal quarter of lumbar spinal cord yielded approximately $45 \mu \mathrm{g}$ total RNA; three lumbar DRGs together yielded approximately $30 \mu \mathrm{g}$ total RNA. These quantities were sufficient for multiple assays to be performed on one tissue sample. It should be noted that this method extracts a much larger amount of tRNA and very small mRN $\Lambda$ s than traditional cesium chloride ultracentrifugation methods. This may result in specific mRNA expression levels per microgram of total RNA that appear lower than those reporled using other exiraction methods (see Results).

Plasmid construction. Six different plasmid constructs were used for the analysis of RNA in this study. Four previously constructed plasmids were used. For the analysis of SP-encoding PPT mRNAs, the pGl$\beta$ PPT and pG2-31-1 ( $\gamma$-PPT) plasmids were used (Krause et al., 1989). For the analysis of NK-1R mRNA, an NK-1R 3' coding region plasmid [pSPR $(+1213 \rightarrow+1800)]$ and a full coding region plasmid $[\mathrm{pSPR}(+577 \rightarrow+1800)]$ were used (Hershey et al., 1991).

In order to quantitate NK-3R mRNA, a plasmid containing 345 bases of the $3^{\prime}$ end of the coding region of the NK-3R cDNA including three bases of the $3^{\prime}$ untranslated region (Shigemoto et al., 1990) was constructed. An NK-3R insert was generated using the polymerase chain reaction ( $\mathrm{PCR}$ ) with buffer conditions, taq polymerase, and a thermal cycler from Perkin-Elmer Cetus Corp. (Norwalk, CT). The oligonucleotides used corresponded to the $3^{\prime}$ end of the seventh transmembrane domain $\left(5^{\prime}+1014\right.$ CAACCCCATCATCTACTGCT $\left.+10333^{\prime}\right)$ and to the opposite strand of the $3^{\prime}$ end of the coding region $\left(5^{\prime}+1359\right.$ TTAGGAATATTCATCCA + 1343 3'; Shigemoto et al., 1990). These oligonucleotides were synthesized by the Washington University Protein Chemistry Facility. PCR was carried out for 30 cycles, and $20 \%$ of the reaction product was analyzed by electrophoresis on a $1 \%$ agarose gel prior to its isolation and molecular cloning. The resulting PCR fragment was cloned into the HincII restriction site of pBLUESCRIPT (Stratagene, La Jolla, CA). The sequence of the receptor insert was confirmed by chain termination methods (Sanger et al., 1987) with T7 and T3 primers using the Sequenase nucleotide sequencing system as recommended by the manufacturer (U.S. Biochemical, Cleveland, $\mathrm{OH}$ ). The resulting plasmid was called pBS-rNKBR $(+1014 \rightarrow+1359)$.

Another plasmid was constructed for $\beta$-actin mRNA analysis. A 210 base Sau $3 A$ restriction fragment of the rat $\beta$-actin cDNA clone pR$\beta A 1$ (a gift of Dr. K. L. O'Malley, Washington University School of Medicine) was isolated and subcloned into the BamHI restriction site of pBLIJESCRIPT. The identity of the insert as rat $\beta$-actin cDNA (Nudel et al., 1983) was confirmed by restriction digest mapping and by specific hybridization to a BglI restriction fragment of $\mathrm{pR}-\beta \mathrm{Al}$. This plasmid was called $\mathrm{pBS}-\mathrm{r} \beta \mathrm{A}_{210}$.

$C R N A$ transcription reactions and quantitation of $c R N A$ standards. Antisense ${ }^{32} \mathrm{P}$-labeled $c R N A$ probes were synthesized using $\alpha{ }^{-32} \mathrm{P}-\mathrm{UTP}$ $(3000 \mathrm{Ci} / \mathrm{mmol})$ from Amersham (Arlington Heights, IL). The plasmid pG1- $\beta$ PPT was lintearized with HindIII and a cRNA probe generated using T7 RNA polymerase (Promega Biotec, Madison, WI). This resulted in an antisense cRNA probe of 567 bases $(508$ bases coding sequence, 59 bases vector) with a specific activity of $4.5 \times 10^{8} \mathrm{dpm} /$ $\mu \mathrm{g} . \mathrm{pSPR}(+1213 \rightarrow+1800)$ or $\mathrm{pBS}-\mathrm{r} \beta \mathrm{A}_{210}$ was linearized with $\mathrm{XbaI}$ and 
antisense probes generated using T7 RNA polymerase. For the NK-I R plasmid an antisense cRNA probe of 696 bases ( 588 bases coding sequence, 108 bases vector) was generated at a specific activity of $3.5 \times$ $10^{8} \mathrm{dpm} / \mu \mathrm{g}$. For the $\beta$-actin plasmid the antisense cRNA probe was 293 bases ( 210 bases coding sequence, 83 bases vector) with a specific activity of $3.9 \times 10^{8} \mathrm{dpm} / \mu \mathrm{g}$. The NK-3R plasmid pBSrNKBR $(+1014 \rightarrow+1359)$ was linearized with $\mathrm{Xhol}$ and an antisense RNA probe generated using T3 polymerase (Boehringer-Mannheim, Indianapolis, IN). This resulted in an antisense cRNA probe of 447 bases ( 345 bases coding sequence, 102 bases vector) with a specific activity of $5.3 \times 10^{8} \mathrm{dpm} / \mu \mathrm{g}$.

Unlabeled message-sense cRNAs were also generated for use as quantitation standards in nuclease protection assays. pG2-31-1 ( $\gamma$-PPT) was linearized with EcoRI; $\operatorname{pSPR}(+577 \rightarrow+1800)$ and pBSrNKBR $(+1014 \rightarrow+1359)$ were linearized using $X$ bal, and synthetic mRNAs were generated from all three using T7 RNA polymerase. pBS$r \beta A_{210}$ was linearized with Xhol and sense RNA generated using T3 RNA polymerase. All transcription reactions were carried out using procedures suggested by Promega. Template DNA was subsequently digested using RQ1 DNase (Promega). Message-sense cRNAs were quantitated using spectrophotometric analysis and confirmed by electrophoresis and subsequent visualization of similar amounts of each cRNA $(0.1-1.0 \mu \mathrm{g})$ with a quantitative RNA size ladder (Promega) on denaturing polyacrylamide gel using the Mighty Small II minigel apparatus (Hoefer, San Francisco, CA). These gels were stained and fixed for $10 \mathrm{~min}$ with $0.1 \%$ bromphenol blue in $10 \%$ acetic acid and destained in distilled water for $1 \mathrm{hr}$, allowing visualization of the cRNA species and comparative quantitation with the RNA size standards.

Solution hybridization-nuclease protection assays and slot blot RNA analysis. The RNA samples were assayed for PPT, NK-1R, or NK-3R mRNAs using solution hybridization-nuclease protection assays. DRG samples were assayed for SP-encoding PPT mRNAs and spinal cord samples were assayed for both NK-1R and NK-3R mRNAs. The use of protection assays to quantitate SP-encoding and NK-1 encoding mRNAs has been described previously (Krause et al., 1987, 1989; Hershey and Krause, 1990; Hershey et al., 1991). NK-3R mRNAs were quantitated similarly. Briefly, $2 \times 10^{5} \mathrm{dpm}$ of the specific "P-labeled antisense cRNA probe was coprecipitated with $5-10 \mu \mathrm{g}$ of total cellular RNA, cRNA quantitation standards $(0.5-7.0 \mathrm{pg})$, or Escherichia coli tRNA negative controls (each sample was made up to $25 \mu \mathrm{g}$ with $E$. coli tRNA), and the precipitate was resuspended in $10 \mu \mathrm{l}$ of hybridization butter [40 mM PIPES, pH 6.4, $400 \mathrm{~mm} \mathrm{NaCl}, 1 \mathrm{~mm}$ EDTA, $80 \%(\mathrm{v} / \mathrm{v})$ deionized formamide]. The RNAs were allowed to anneal with cRNA probes for $16-20 \mathrm{hr}$ at $45^{\circ} \mathrm{C}$. Annealed portions of the mRNAs were protected from nuclease digestion, which was performed for $30 \mathrm{~min}$ at $37^{\circ} \mathrm{C}$. Nuclease $S_{1}\left(1000 \mathrm{U} / \mathrm{ml}\right.$; Sigma) was used for PPT assays; $S_{1}$ digestion was terminated by addition of $75 \mu \mathrm{l}$ of stop buffer $(2.5 \mathrm{M}$ $\mathrm{NH}_{4} \mathrm{O}$-acetate, $50 \mathrm{~mm}$ EDTA). Nucleases A (40 $\mu \mathrm{g} / \mathrm{ml}$; Sigma) and $\mathrm{T}_{1}$ ( $2 \mu \mathrm{g} / \mathrm{ml}$; Sigma) were used for NK-1R and NK-3R assays; nuclease digestion was followed by a 15 min digestion with proteinase $\mathrm{K}(100$ $\mu \mathrm{g} / \mathrm{sample}$; Boehringer-Mannheim). Digestion reactions were precipitated with an equal volume of 2-propanol prior to resuspension and electrophoresis at $25 \mathrm{~V} / \mathrm{cm}$ on $6 \%$ acrylamine gels containing $7 \mathrm{~m}$ urea. Gels were fixed, dried, and exposed to Hyperfilm autoradiographic film (Amersham) at $-80^{\circ} \mathrm{C}$ with an overlying intensifying screen. Densitometric analysis of the resulting autoradiograms was performed using a Bio-Kad model 620 video densitometer (Richmond, CA). Lanes were scanned individually to allow removal of small lane-to-lane variations in background intensity. Autoradiographic signals for the total RNA samples were compared to those for the message-sense cRNA quantitation standards in order to calculate the relative amount of specific mRNA in each total RNA sample.

The use of denaturing acrylamide gels to separate protected RNA species by electrophoretic mobility allows the precise determination of specific mRNA species. The nuclease protection assay is a more sensitive detection method than Northern blot analysis since hybridization with the antisense cRNA probe is driven essentially to completion. However, this increased sensitivity can easily be lost or masked by the overexposure of the autoradiograms. Overexposure can result in minimization or obliteration of subtle variations in signal intensities. It was imperative that exposure times resulted in signal intensities within the linear response range of the film used (Krause et al., 1989). In this study, exposures varying from $18 \mathrm{hr}$ to $5 \mathrm{~d}$ were made from gels of each assay type to determine the appropriate (nonsaturating) exposure time for RNA samples in each assay. This resulted in autoradiograms on which the signals for $\mathrm{cRNA}$ standards were linearly related to the mass amount of $\mathrm{cRNA}$ run on the gel.

$\beta$-Actin mRNA was quantitated by hybridizing slot blots of individual RNAs to the ${ }^{32} \mathrm{P}$-labeled antisense cRNA probe generated using the pBS-r $\beta A_{210}$ plasmid. Aliquots of total RNA samples $(0.1 \mu \mathrm{g}$ and $1.0 \mu \mathrm{g})$ were applied through a Schleicher \& Schuell (Keene, NH) Minifold II slot blot apparatus in $400 \mu \mathrm{l}$ of elution buffer [ $4.5 \mathrm{M}$ formaldehyde, $10 \times$ standard sodium citrate (SSC)] onto Nytran nylon membranes (Schleicher \& Schuell). Aliquots of message-sense cRNA (20-200 pg) were included as quantitation standards, and $E$. coli tRNA was used as a negative control RNA. The manifold wells were then washed with 400 $\mu \mathrm{l}$ of $10 \times$ SSC. The resulting slot blots were dried at room temperature for $20 \mathrm{~min}$ and then fixed in a vacuum oven at $80^{\circ} \mathrm{C}$ for $2 \mathrm{hr}$. Before hybridization, blots were preincubated at $55^{\circ} \mathrm{C}$ for $1 \mathrm{hr}$ in hybridization buffer (Krause et al., 1987). Hybridization was performed for $24 \mathrm{hr}$ at $55^{\circ} \mathrm{C}$ in hybridization buffer containing $1 \times 10^{6} \mathrm{cpm} / \mathrm{ml}{ }^{32} \mathrm{P}$-cRNA probe, and the blots subsequently washed four times for $15 \mathrm{~min}$ at $65^{\circ} \mathrm{C}$ in $500 \mathrm{ml}$ of wash buffer ( $1 \times \mathrm{SSC}, 0.1 \% \mathrm{SSPE})$. Northern blots of spinal cord RNA were included with the slot blots during hybridization in order to ensure that the resulting $\beta$-actin signal : noise ratio was acceptable. The hybridized slot blots were then subjected to autoradiographic and densitometric analysis similar to that used for protection assays.

Statistical analysis. Data were analyzed using analysis of covariance, and Dunnett's test was used for post hoc comparisons. Analysis of covariance was used because the error between assays significantly contributed to the error between treatment groups. Significance was considered to be $p \leq 0.05$. All data are expressed as picograms of specific $\mathrm{mRNA} / \mathrm{ng} \beta$-actin mRNA (mean $\pm \mathrm{SEM}$ ), and all comparisons were made to naive controls of the same side.

\section{Results}

Schematic illustrations of the cRNA probes used in this study along with results from representative nuclease protection experiments are shown in Figures 1-3. In all assays discussed below, the autoradiographic signals from message-sense cRNAs and tissue RNA samples were linear with respect to mass of cRNA, and expression levels of the control $\beta$-actin RNA were not altered by any nociceptive treatment (the variability of $\beta$-actin expression between individuals was greater than the variability of $\beta$-actin levels between treatment groups). Thus, $\beta$-actin was considered an appropriate control species for the normalization of peptide and receptor mRNA expression. An assay for SP-encoding PPT mRNAs is shown in Figure $1 A$. Three protected bands are visible for the RNA species protected by $\beta$-PPT (508 bases) and $\gamma$-PPT (295 and 168 bases) mRNAs; the bands protected by the less abundant $\alpha$-PPT mRNA ( 364 and 90 bases) are not visible in this exposure. There was no evidence of any alteration of the normal ratio of PPT mRNAs ( $<1 \%: 20 \%: 80 \%$, $\alpha: \beta: \gamma$; Krause et al., 1987) following either formalin or CFA treatments. Some residual undigested cRNA probe (567 bases) was still visible after nuclease digestion but did not interfere with quantitation of any specific signals. Quantitation of PPT $m$ RNAs was obtained by analysis of the 295 base band protected by $\gamma$-PPT mRNA (see Fig. $1 B$ ). This band accounted for $64 \%$ of the mass of $\gamma$-PPT mRNA present, and thus represents about $50 \%$ of the total PPT mRNAs present in lumbar DRG. Each DRG sample represents the signal protected by $5 \mu \mathrm{g}$ of total RNA isolated from three lumbar DRGs obtained from a single rat. Average $\gamma$-PPT mRNA expression levels for the left and right lumbar DRGs in naive subjects were $10.5 \pm 1.4$ and 11.4 $\pm 1.7 \mathrm{pg} / \mathrm{ng} \beta$-actin mRNA, respectively (approximately $3.2 \mathrm{pg}$ of $\gamma$-PPT mRNA/ $\mu$ g DRG total RNA).

Figure $2 A$ shows representative results from an NK-1 R assay. Each sample lane shows one protected band ( 588 bases) using $10 \mu \mathrm{g}$ of total RNA from the right lumbar dorsal horn of a single subject and some residual undigested cRNA probe (696 bases). 
A.

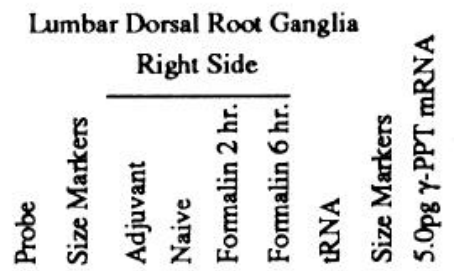

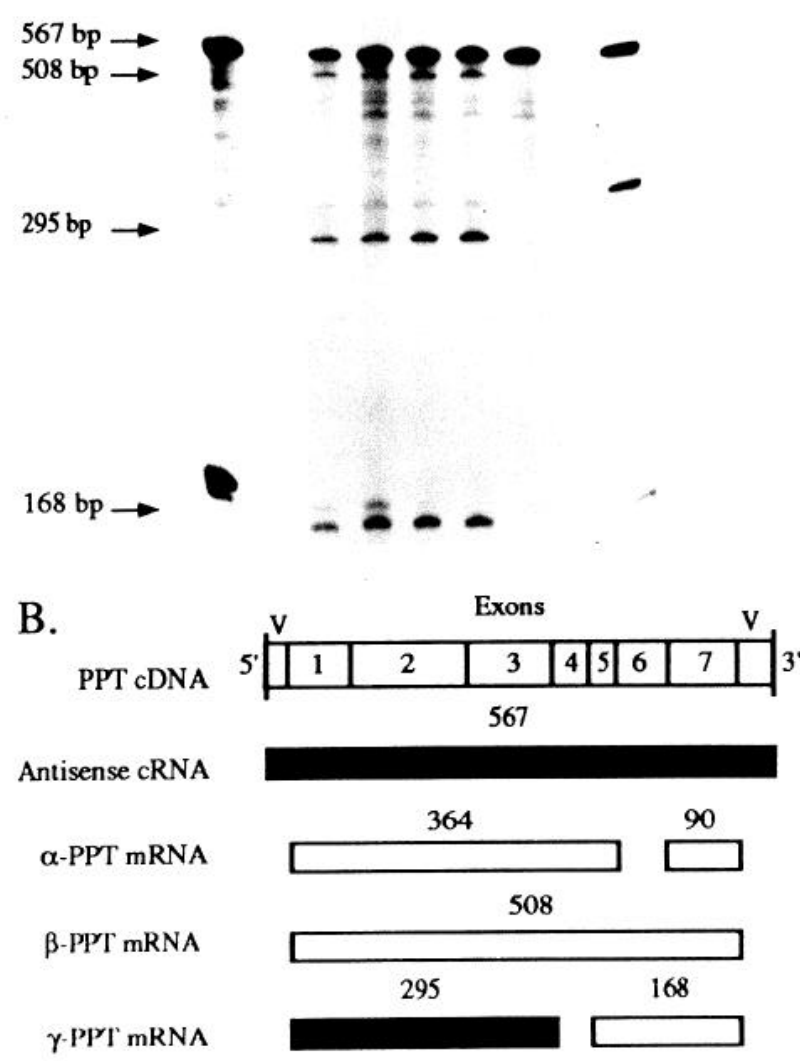

Figure 1. A, Autoradiogram of a representative solution hybridization-nuclease protection assay for SP-encoding PPT mRNAs. The $a r-$ rows show the sizes of the undigested cRNA probe ( 567 bases), and the RNA species protected by $\gamma$-PPT mRNAs ( 295 and 168 bases) and a message-sense $\gamma$-PPT cRNA quantitation standard (295 bases) on the autoradiogram of the denaturing urea-polyacrylamide gel. The 295 base band protected by $\gamma$-PPT mRNA was analyzed in order to quantitate total PPT mRNA expression levels (see Results). In this example, the $\gamma$-PPT mRNA signal from the DRG of the adjuvant-treated subject is less intense than signal representative of the mean for this treatment group. Each lane in these assays represents only one individual; thus, treatment effects may not be fully appreciable by viewing only one assay. $B$, A schematic diagram showing sizes of the PPT cDNA, cRNA probe, and protected mRNA species.

The 588 base protected bands and cRNA standards were used for quantitation of NK-1R mRNA. Average NK-1R mRNA expression levels for the left and right lumbar dorsal horns in naive subjects were $1.36 \pm 0.17$ and $1.08 \pm 0.12 \mathrm{pg} / \mathrm{ng} \beta$-actin mRNA, respectively (approximately $0.41 \mathrm{pg}$ of NK-1R mRNA/ $\mu \mathrm{g}$ dorsal horn total RNA). These NK-1R mRNA expression levels are similar to but somewhat less than those reported by Tsuchida et al. (1990) or Hershey et al. (1991). This may be due to differences in total RNA extraction techniques (see Materials and Methods). In the lumbar ventral horns, NK-1R mRNA expression levels for the left and right sides of naive
A.

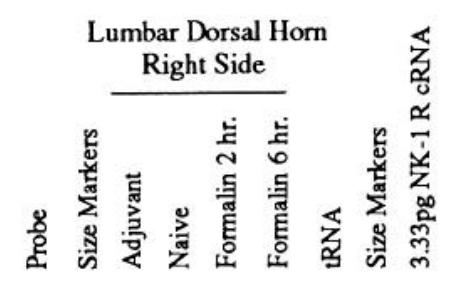

B.
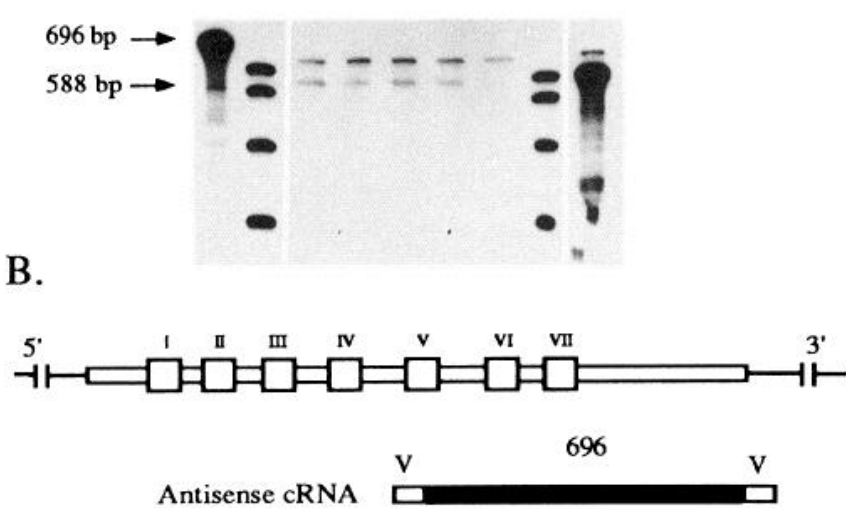

588

Protected Fragment

Figure 2. A, Autoradiogram of a representative solution hybridization-nuclease protection assay for NK-1R mRNA. The arrows show the sizes of the undigested cRNA probe (696 bases) and RNA species protected by NK-1R mRNA ( 588 bases) and a message-sense NK-1R cRNA quantitation standard 588 bases) on the autoradiogram. The 588 base protected band was analyzed for quantitation of NK-1R mRNA. $B$, A schematic diagram showing sizes of the NK-1R cDNA, cRNA probe, and protected mRNA species. The Roman numerals above the NK-1R cDNA schematic represent putative transmembrane domains of the deduced protein.

subjects were $1.70 \pm 0.17$ and $1.70 \pm 0.10 \mathrm{pg} / \mathrm{ng} \beta$-actin mRNA, respectively (approximately $0.48 \mathrm{pg}$ of $\mathrm{NK}-1 \mathrm{R} \mathrm{mRNA} / \mu \mathrm{g}$ ventral horn total RNA).

Representative results from an NK-3R assay are shown in Figure $3 \mathrm{~A}$. Each sample lane shows the single 345 base band protected using $10 \mu \mathrm{g}$ of total RNA from the right lumbar dorsal horn of a single subject. This autoradiographic signal was used for quantitation of NK-3R mRNA. Also visible are a quantitation standard ( 408 bases) and residual undigested cRNA probe (447 bases and the three less than full-length products apparent in the tRNA and sample lanes). Average NK-3R mRNA expression levels for the left and right lumbar dorsal horns in naive subjects were $2.84 \pm 0.08$ and $2.48 \pm 0.40 \mathrm{pg} / \mathrm{ng} \beta$-actin mRNA, respectively (approximately $0.68 \mathrm{pg}$ of NK-3R mRNA/ $\mu \mathrm{g}$ dorsal horn total RNA). In the lumbar ventral horns, NK3R mRNA expression levels for the left and right sides of naive subjects were $4.76 \pm 0.91$ and $4.34 \pm 1.16 \mathrm{pg} / \mathrm{ng} \beta$-actin mRNA, respectively (approximately $1.02 \mathrm{pg}$ of NK-3R mRNA/ $\mu \mathrm{g}$ ventral horn total RNA).

Figures 4-6 show mRNA changes in subjects receiving nociceptive activations of the hindpaw. Figure 4 shows the effects of formalin or CFA injection on the expression of an SP-encoding PPT mRNA in the L4-L6 DRGs. Formalin treatment showed a trend toward increased $\gamma$-PPT mRNA levels in the ipsilateral L4-L6 DRGs $2 \mathrm{hr}$ after hindpaw treatment (from $11.4 \pm 1.7$ to $16.0 \pm 1.3 \mathrm{pg} / \mathrm{ng} \beta$-actin mRNA). Steady state 
A.
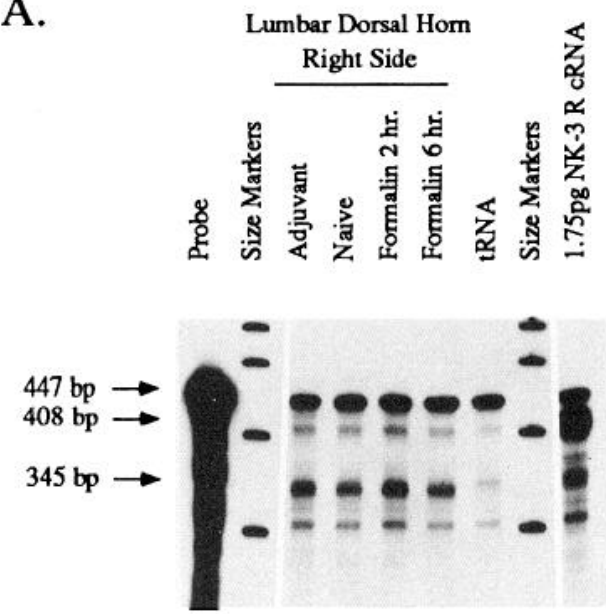

B.

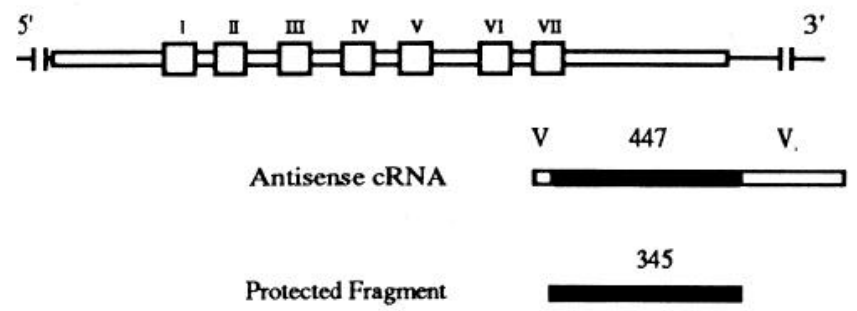

Figure 3. A, Autoradiogram of a representative solution hybridization-nuclease protection assay for NK-3R mRNA. The arrows show the sizes of the undigested cRNA probe ( 447 bases) and the RNA species protected by NK-3R mRNA (345 bases) and a message-sense NK-3R cRNA quantitation standard ( 408 bases) on the autoradiogram. The one major and three minor bands evident in the tRNA lane correspond to undigested full length and incompletely transcribed cRNA probe, respectively. The 345 base protected band was analyzed for quantitation of NK-3R mRNA. $B$, A schematic diagram showing sizes of the NK$3 \mathrm{R}$ cDNA, mRNA probe, and protected mRNA species. The Roman numerals above the NK-3R cDNA schematic represent putative transmembrane domains of the deduced protein.

$\gamma$-PPT mRNA levels had significantly increased to $21.7 \pm 3.9$ $\mathrm{pg} / \mathrm{ng} \beta$-actin mRNA $6 \mathrm{hr}$ after injection of formalin into the hindpaw $(p<0.05)$. Similarly, CFA injection (4 d) significantly increased $\gamma$-PPT mRNA expression in the L4-L6 DRGs to 22.8 $\pm 4.0 \mathrm{pg} / \mathrm{ng} \beta$-actin mRNA only in the ipsilateral lumbar DRG $(p<0.05)$. There was a slight trend toward increased levels of $\gamma$-PPT mRNA in the contralateral DRGs following formalin, but the changes were not significantly different from naive control subjects. It should be noted that although analysis of covariance was used in this study to remove the effects of small variations of mRNA levels in control animals between assays, the use of ANOVA resulted in identical results except that changes in receptor levels marked $p<0.01$ (see below) were only significant at the $p \leq 0.05$ level. In no case was there a significant difference in mRNA expression levels between the ipsi- and contralateral sides of naive control groups.

The effects of nociceptive activations of the hindpaw on NK$1 \mathrm{R}$ mRNA levels in the lumbar enlargement of the spinal cord are shown in Figure 5. Formalin treatment showed a trend toward increased NK-1R mRNA expression in the ipsilateral dorsal horn after $2 \mathrm{hr}$ (from $1.08 \pm 0.12$ to $1.91 \pm 0.31 \mathrm{pg} / \mathrm{ng}$ $\beta$-actin mRNA; in this case, $p$ is greater than but approximately equal to 0.05 ; see Fig. $5 A$ ). Steady state NK-1R mRNA levels

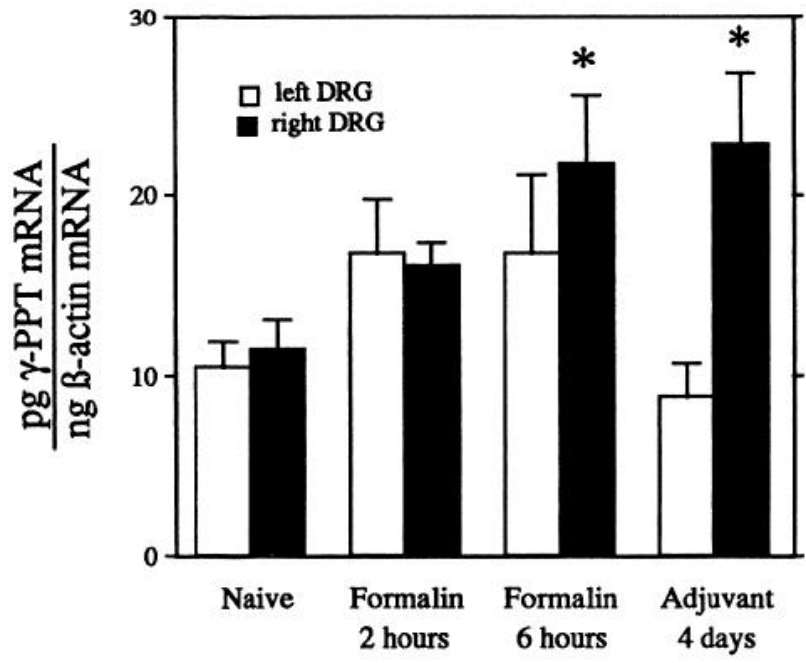

Figure 4. SP-encoding $\gamma$-PPT mRNA expression in the L4-L6 DRG. Note that $\gamma$-PPT mRNA expression is significantly increased in the right L4-L6 DRGs (ipsilateral to hindpaw treatment) $6 \mathrm{hr}$ after formalin injection and $4 \mathrm{~d}$ after adjuvant injection. $\gamma$-PPT mRNA expression in the left L4-L6 DRGs (contralateral to hindpaw treatment) remained unchanged. For quantitation purposes, the 295 base protected species (see Fig. 1) was analyzed for comparison purposes (therefore, these amounts reflect only this portion of the total SP-encoding mRNA species; see Results). ${ }^{*}, p<0.05$ compared to naive controls.

were significantly increased to $2.41 \pm 0.23 \mathrm{pg} / \mathrm{ng} \beta$-actin mRNA $6 \mathrm{hr}$ after injection of formalin into the hindpaw $(p<0.01$; Fig. $5 A$ ). NK-1R mRNA expression was significantly increased to $2.15 \pm 0.40 \mathrm{pg} / \mathrm{ng} \beta$-actin mRNA in the ipsilateral dorsal horn $4 \mathrm{~d}$ after injection of CFA into the hindpaw ( $p<0.05$; Fig. $5 A$ ). Neither treatment produced significant alterations in NK-1R mRNA levels in the contralateral dorsal horn (Fig. $5 A$ ) or in the ventral horn (Fig. 5B). However, there was a trend toward increased NK-1R mRNA levels in the ipsilateral ventral horn after formalin injection (Fig. $5 B$ ).

Figure 6 shows the effects of nociceptive activation of the hindpaw on NK-3R mRNA expression in the lumbar enlargement of the spinal cord. At $2 \mathrm{hr}$ after hindpaw treatment, formalin treatment showed a trend toward increased NK-3R mRNA levels in the ipsilateral dorsal horn (from $2.38 \pm 0.40$ to 3.83 $\pm 0.80 \mathrm{pg} / \mathrm{ng} \beta$-actin mRNA; Fig. $6 A$ ). Steady state NK-3R mRNA levels were significantly increased to $5.25 \pm 0.37 \mathrm{pg} / \mathrm{ng}$ $\beta$-actin mRNA $6 \mathrm{hr}$ after injection of formalin into the hindpaw $(p<0.01$; Fig. $6 A)$. The expression level of NK-3R mRNA was significantly increased to $4.57 \pm 0.72 \mathrm{pg} / \mathrm{ng} \beta$-actin mRNA in the ipsilateral dorsal horn $4 \mathrm{~d}$ after injection of CFA into the hindpaw $(p<0.05$; Fig. $6 A)$. Neither treatment produced significant alterations in NK-3R mRNA expression in the contralateral dorsal horn (Fig. 6A) or in the ventral horn (Fig. $6 B$ ).

\section{Discussion}

The results of this study demonstrate that nociceptive activation of the periphery can result in altered tachykinin receptor mRNA expression in the spinal cord. Nociceptive activation of SPcontaining primary afferent neurons produces an upregulation in the production of SP-encoding mRNAs in primary afferent neurons, presumably providing substrate for increased SP production, release, and turnover in the dorsal horn and periphery. The twofold increase in $\gamma$-PPT mRNA expression in the lumbar DRG evoked by formalin or CFA (Fig. 4) reflects the previous 

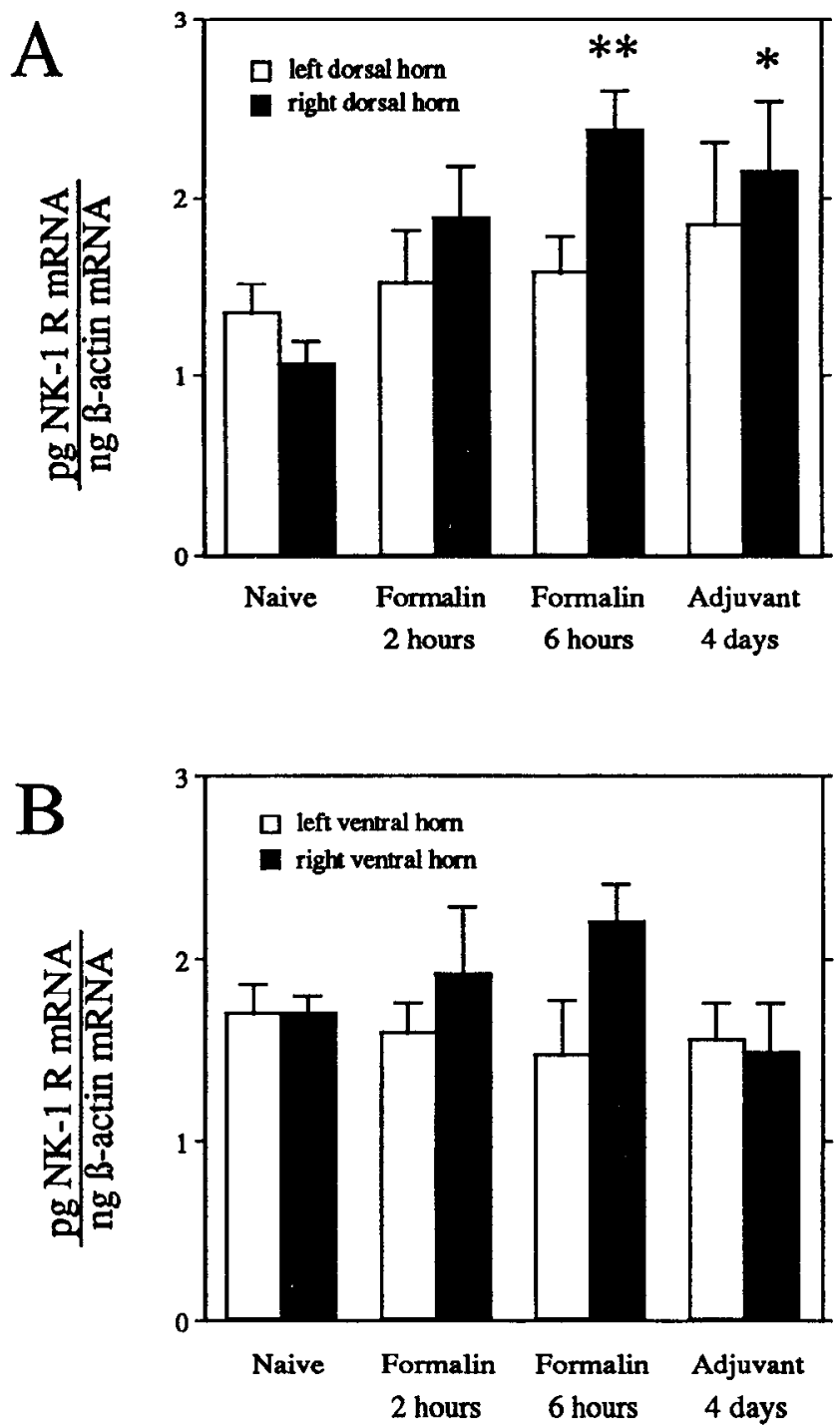

Figure 5. NK-1R mRNA expression in the spinal cord. $A$, Dorsal horn. Note that NK-1R mRNA expression is significantly increased in the right dorsal horn (ipsilateral to hindpaw treatment) $6 \mathrm{hr}$ after formalin injection and $4 \mathrm{~d}$ after adjuvant injection. NK-1R mRNA expression in the left dorsal horn (contralateral to hindpaw treatment) remained unchanged. $B$, Ventral horn. NK-IR mRNA levels in the spinal cord ventral horn are not significantly altered by either nociceptive treatment. $*, p<0.05 ;{ }^{* *}, p<0.01$; compared to naive controls.

findings of other investigators using in situ hybridization and dot-blot hybridization techniques (Noguchi et al., 1988; Minami et al., 1989; Donaldson et al., 1992). The results of this study are also consistent with the findings of Noguchi et al. (1988), in that significant upregulation of PPT mRNA expression during nociception takes at least $2 \mathrm{hr}$ (see Fig. 4). This study provides the first evidence for altered NK- 1 and NK-3 tachykinin receptor mRNA expression during nociception. Subsequent alterations in the expression or sensitivity of tachykinin receptors at the cell surface may play an important role in determining physiological responses to long-term nociceptive activation.

The nociceptive activations used in this study (formalin or CFA injection into a single hindpaw) have both been widely used as models of subchronic nociception (Dubuisson and Dennis, 1977; Kantner et al., 1985; Oku et al., 1987; ladarola et al., 1988a,b; Noguchi et al., 1988; McCarson and Goldistein 1989,
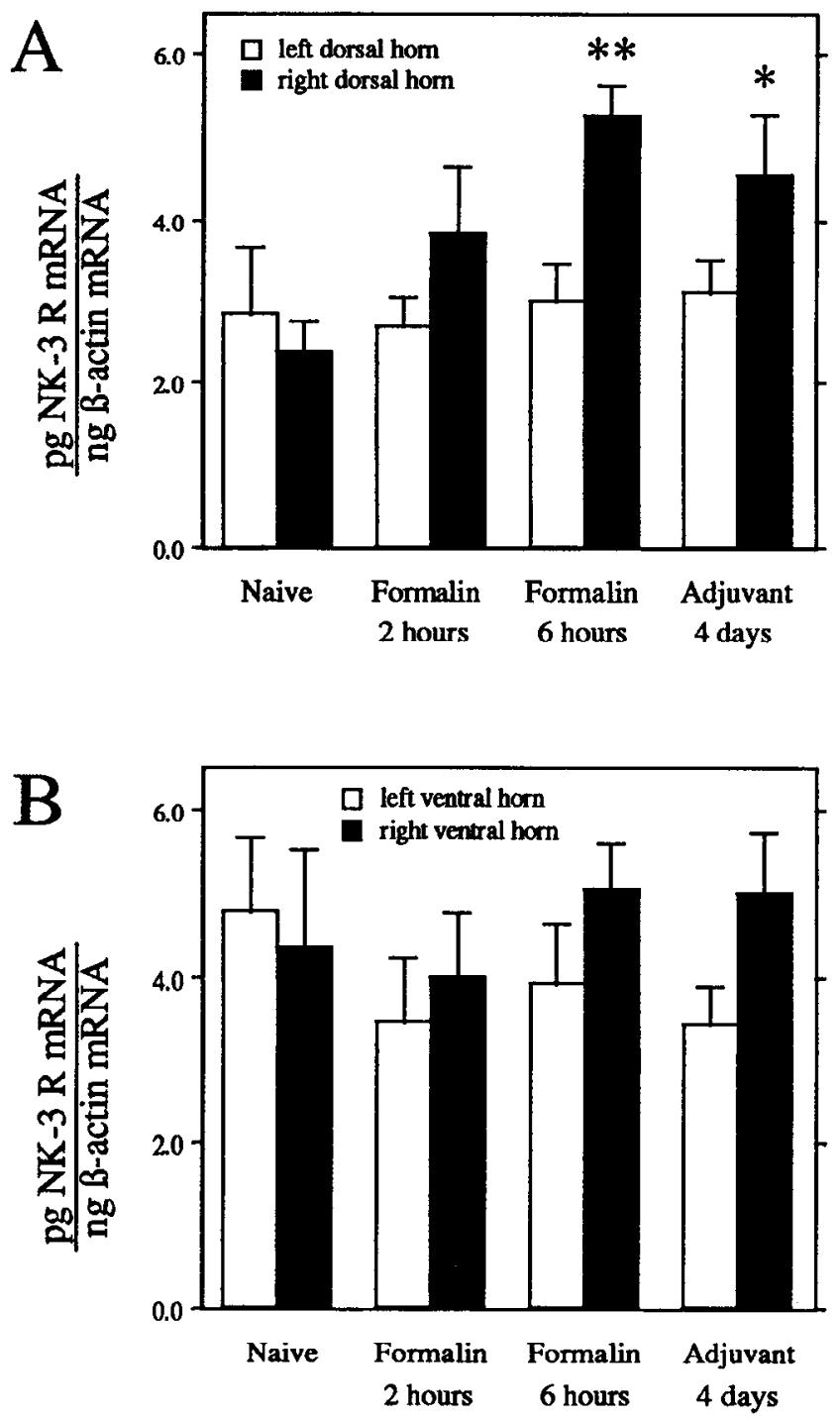

Figure 6. NK-3R mRNA expression in the spinal cord. $A$, Dorsal horn. Note that NK-3R mRNA expression is significantly increased in the right dorsal horn (ipsilateral to hindpaw treatment) $6 \mathrm{hr}$ after formalin injection and $4 \mathrm{~d}$ after adjuvant injection. NK-3R mRNA expression in the left dorsal horn (contralateral to hindpaw treatment) remained unchanged. $B$, Ventral horn. NK-3R mRNA expression in the spinal cord ventral horn is not significantly altered by either nociceptive treatment. ${ }^{*}, p<0.05 ;{ }^{* *}, p<0.01$ compared to naive controls.

1990, 1991; Minami et al., 1989; Noguchi and Ruda, 1992; Tjolsen et al., 1992; Yashpal et al., 1993). The time points after formalin or CFA injection were chosen for this study based on the results of previous studies. Formalin injection into the hindpaw has been shown to increase the amount of immunoreactive SP in the dorsal horn after $1 \mathrm{hr}$ (Kantner et al., 1985; McCarson and Goldstein, 1989, 1990). Similarly, formalin injection increases the number of cells in the lumbar DRG expressing SPencoding PPT mRNAs as early as $3 \mathrm{hr}$ postinjection (Noguchi et al., 1988). The use of adjuvant as a nociceptive activator increases the expression of SP-encoding PPT mRNAs in the lumbar spinal cord and DRG within 8 hr (Donaldson et al., 1992) to $4 \mathrm{~d}$ (Minami et al., 1989) and upregulates expression of both dynorphin and enkephalin mRNAs in the dorsal horn of the spinal cord within 3-4 d (Iadarola et al., 1988a,b). The level of PPT mRNAs and the numbers of cells expressing PPT 
mRNA in the dorsal horn of the spinal cord are increased within $4 \mathrm{~d}$ after CFA, indicating that SP-containing spinal interneurons may play a role in nociceptive processing (Noguchi and Ruda, 1992).

The role of SP in spinal mechanisms of pain transmission has been widely studied. There is a large body of evidence that associates intrathecal injections of SP with nociceptive behavior (Piercey et al., 1981; Hylden and Wilcox, 1983a) and decreased nociceptive threshold (Doi and Jurna, 1981; Hylden and Wilcox, 1983b; Matsumura et al., 1985). The release of SP from primary afferent neurons can be stimulated by a number of different peripheral manipulations including electrical stimulation of the sciatic nerve (Yaksh et al., 1980), noxious mechanical pinch of the hindpaw (Kuraishi et al., 1983; McCarson and Goldstein, 1991), or adjuvant-induced arthritis of the hindpaw (Oku et al, 1987). In the dorsal horn of the spinal cord, the majority of SP is found in the central terminals of smalldiameter finely myelinated $(\mathrm{A}-\delta)$ and unmyelinated $(\mathrm{C})$ primary afferent fibers (Hokfelt et al., 1975; Barber et al., 1979). Only $20-50 \%$ is contained in intrinsic or descending neurons (Jessell et al., 1979; Ogawa et al., 1985). SP-containing afferent neuron terminals have been shown to appose nociception-specific dorsal horn neurons (DeKoninck et al., 1992). Therefore, a likely source of SP for the activation of NK-1 receptors is that released from primary afferent neurons that can be activated by nociception.

If alterations in SP production and release produce direct effects on nociceptive processing in the dorsal horn, then the NK-1 receptors found in the dorsal horn might be expected to play a functional role in nociceptive processing. In the spinal cord, NK-1 receptors are found primarily in the superficial dorsal horn (laminae I and II) in the region of termination of SPcontaining primary afferent neurons (Helke et al., 1990; Yashpal et al., 1990). Immunohistochemical studies conducted using recently generated polyclonal antibodies directed toward an amino terminal portion of the $\mathrm{NK}-1$ receptor have confirmed the localization of the NK-1 receptor protein in laminae I and II of the dorsal horn (Moussaoui et al., 1992). There is evidence that NK-1 receptors exist primarily on nociception-specific second-order projection neurons in the superficial dorsal horn. For example, it has been demonstrated that dorsal horn cells, electrophysiologically classified as nociception specific, are activated by exogenously applied SP (Henry, 1976; Salter and Henry, 1991). Importantly, the activation of these nociception-specific dorsal horn cells by SP or noxious peripheral stimuli can be blocked specifically by the nonpeptide NK-1 receptor antagonist CP-96,345 (Radhakrishnan and Henry, 1991) or by peptide NK-1 receptor antagonists (Cridland and Henry, 1988). CP96,345 does not alter acute responses to noxious thermal stimuli, but has been shown to block the hyperalgesic effects of intrathecal injections of SP or immersion of the tail tip in hot water (a model of endogenous SP release in the spinal cord; Yashpal et al., 1993). Also, CP-96,345 attenuates only the late phase of the formalin response (Yamamoto and Yaksh, 1991; Yashpal et al., 1993), indicating that SP activation of the NK-1 receptor may only play a role in mediating hyperalgesia or long-term states of nociception. Thus, upregulation of SP turnover in primary afferent neurons during nociception may result in increased NK-1 receptor stimulation in the dorsal horn of the spinal cord. The increased tachykinin receptor mRNA expression seen in this study may occur due to increased agonist activation of NK-1 receptors or by increased electrical activity in dorsal horn cells. In either case, second messengers or other downstream medi- ators could activate transcriptional mechanisms. However, the precise mechanisms by which gene expression is activated during nociception are not understood.

Homologous changes in receptor gene expression during pharmacological alteration of surface receptors level have been described in other G-protein-coupled receptor systems (Collins et al., 1992). For example, agonist stimulation of the $\beta_{2}$ adrenergic receptor has been shown to increase homologous receptor gene transcription directly by three- to fourfold via activation of its second messenger, cAMP (Collins et al., 1989). The mechanism of action of SP at the NK-1 receptor involves phospholipase C-mediated phosphoinositol hydrolysis (Hanley et al., 1980). The products of this hydrolysis, inositol trisphosphate and diacylglycerol, have been shown to mobilize internal $\mathrm{Ca}^{2+}$ stores (Streb et al., 1983) and activate protein kinase C, respectively (Kishimoto et al., 1980). The 5'-flanking region of the NK-1R gene has been shown to include recognition sequences identical to the $\mathrm{Ca}^{2+}$ inducibility sequence of $c-f o s$ and the cAMP response element, indicating that receptor activation may trigger gene transcription (Hershey et al., 1991). A homologous mechanism for the upregulation of NK-1R gene expression through activation of the NK-1 receptor by SP is consistent with the wealth of evidence implicating SP in the transmission of pain (see above). Alternatively, this mechanism may be heterologous; that is, increased activity of a different neurotransmitter (e.g., excitatory amino acids) may be responsible for alterations in tachykinin receptor mRNA expression. A heterologous activation mechanism has been proposed for the upregulation of preprodynorphin mRNA in the dorsal horn after CFA (Dubner and Ruda, 1992). The inhibition of SP release in to the superficial dorsal horn after formalin injection (McCarson and Goldstein, 1991) supports the notion that another transmitter may be responsible for the increased tachykinin receptor mRNA expression demonstrated in this study. Nociception has been shown to evoke the release of many other neuroactive substances such as enkephalin, somatostatin, and excitatory amino acids (Yaksh and Elde, 1981; Kuraishi et al., 1985; Skilling et al., 1988). Furthermore, it is not known whether changes in tachykinin receptor mRNA expression level seen in this study are due to transcriptional or posttranscriptional mcchanisms. The NK-1R gene 3'-untranslated region contains pentanucleotide sequence repeats (ATTTA) that may affect mRNA stability and allow rapid turnover of the mature transcript (Ihara and Nakanishi, 1990; Hershey et al., 1991; J. Takeda and J. E. Krause, unpublished observations). It remains to be determined whether the nociceptive paradigms used in this study result in an increased number of functional tachykinin receptors being inserted into receptive areas of the plasma membrane or in increased responsiveness of previously expressed receptors. We hypothesize that changes in steady state receptor mRNA levels could act to reset the sensitivity of dorsal horn cells by altering either receptor number, coupling to G-proteins, or effector activity.

Much less is known about the role that NKB and the NK-3 receptor play in nociception. The majority of NKB mRNA is expressed in cell bodies in lamina III of the dorsal horn (Warden and Young, 1988), primarily in intrinsic spinal neurons (Ogawa et al., 1985). The NK-3 receptor (Shigemoto et al., 1990) is found in the superficial dorsal horn of the spinal cord (Mantyh et al., 1989; Yashpal et al., 1990). NKB has the highest affinity of the tachykinins for the NK-3 receptor (Helke et al., 1990), and the NK-3 site has been shown to mediate the antinociceptive effects of NKB (Couture et al., 1992). Intrathecal injections 
of NKB have been shown to have antinociceptive effects (Laneuville et al., 1988). Pretreatment with naloxone blocked these effects, indicating that the antinociceptive effects of NKB are mediated by endogenous opiate substances (Laneuville et al., 1988). This antinociceptive activation by NKB may be similar or identical to that described for endogenous opiate systems (Henry, 1983), and may involve segmental or ascending-descending neuronal reflex systems. Endogenous opiates have been shown to affect dorsal horn SP immunoreactivity during nociception (McCarson and Goldstein, 1989, 1990). Thus, nociception may trigger increased activity of an intrinsic antinociceptive system (mediated via NKB and endogenous opiates) that could act not only to limit or modify transmission of nociceptive information to higher brain centers but also to alter turnover of SP and/or tachykinin receptors locally in the dorsal horn. The increase in steady state NK-3R mRNA levels during nociception demonstrated in this study suggests that cells expressing the NK-3 receptor in the dorsal horn may be activated by nociception. Translation of increased levels of NK-3 receptor mRNA and presumably the elevation of functional NK-3 receptors may contribute to alterations in nociceptive processing. The gene encoding this rat tachykinin receptor has not been characterized to our knowledge, and the molecular mechanisms involved in NK-3 receptor expression are not known.

The results of this study also indicate that expression levels of NK-3 receptor $\mathrm{mRNA}$ in the spinal cord dorsal horn are twoto threefold higher than those of NK-1 receptor mRNA (see Figs. 5, 6). However, previous quantitative autoradiographic studies (using subsaturating agonist concentrations) indicate the presence of more NK-1 sites than NK-3 sites in the dorsal horn (Yashpal et al., 1991). This apparent discrepancy could arise if many small cells (e.g., interneurons) express low levels of NK-3 receptor $\mathrm{mRNA}$ and few cells (e.g., laminae $I$ and II dorsal horn cells) express high levels of NK-1 receptor mRNA. An individual mRNA may also have different translation efficiencies in various cell types. Additionally, different translation efficiencies may result from intrinsic differences in mRNA sequences that dictate the efficiency of mRNA binding to the $40 \mathrm{~S}$ ribosomal subunit. For these and other reasons, there may simply be a lack of lincarity between amount of steady state receptor mRNAs, amount of mature receptor proteins expressed on the cell surface, and extent of receptor coupling to G-protein(s).

In conclusion, nociception has been shown to alter SP mRNA expression in the DRG and NK-1 and NK-3 type tachykinin receptor $\mathrm{mRNA}$ expression in the dorsal horn of the spinal cord. The precise mechanisms are not known, but long-term nociceptive activation of small-diameter afferent neurons may provide a neuronal drive for upregulation of tachykinin receptor mRNA expression in dorsal horn cells and alteration of dorsal horn cell sensitivity. The neuronal changes that occur during long-term nociception may provide the bases for new interpretations of the role that tachykinins and their receptors play in nociception, and perhaps in the future treatment of chronic pain syndromes.

\section{References}

Barber RP, Vaughn JE, Slemmon JR, Salvattera PM, Roberts E, Leeman SE (1979) The origin, distribution, and synaptic relationships of substance $P$ axons in rat spinal cord. J Comp Neurol 184:331-352.

Chomczynski P, Sacchi N (1987) Single-step method of RNA isolation by acid guanidinium thiocyanate-phenol-chloroform extraction. Anal Biochem 162:156-159.

Collins S, Bouvier M, Bolanowski MA, Caron MG, Lefkowtiz RJ (1989)
cAMP stimulates transcription of the $\beta_{2}$-adrenergic receptor gene in response to short-term agonist exposure. Proc Natl Acad Sci USA 86:4853-4857.

Collins S, Caron MG, Lefkowitz RJ (1992) From ligand binding to gene expression: new insights into the regulation of $\mathrm{G}$-protein-coupled receptors. Trends Biochem Sci 17:27-29.

Couture R, Boucher S, Picard P, Regoli D (1992) Receptor characterization of the spinal action of neurokinins on nociception: a three receptor hypothesis. Regul Pep [Suppl] 1:S48.

Cridland RA, Henry JL (1988) Facilitation of the tail-flick reflex by noxious cutaneous stimulation in the rat: antagonism by a substance $P$ analogue. Brain Res 462:15-21.

DeKoninck Y, Ribeiro-da-Silva A, Henry JL, Cuello C (1992) Spinal neurons exhibiting a specific nociceptive response receive abundant substance P-containing synaptic contacts. Proc Natl Acad Sci USA 89:5073-5077.

Doi T, Jurna I (1981) Intrathecal substance P depresses the tail-flick responsc-antagonism by naloxone. Naunyn Schmiedebergs Arch Pharmacol 317:135-139.

Donaldson LF, Harmar AJ, McQueen DS, Seckl JR (1992) Increased expression of preprotachykinin, calcitonin gene-related peptide, but not vasoactive intestinal peptide messenger RNA in dorsal root ganglia during the development of adjuvant monoarthritis in the rat. Mol Brain Res 16:143-149.

Dubner R, Ruda MA (1992) Activity-dependent neuronal plasticity following tissue injury and inflammation. Trends Neurosci 15:96103.

Dubuisson D, Dennis SG (1977) The formalin test: a quantitative study of the analgesic effects of morphine, meperidine, and brain stem stimulation in rats and cats. Pain 4:161-174.

Hanley MR, Lee CM, Jones LM, Michell RH (1980) Similar effects of substance $P$ and related peptides on salivation and phosphatidylinositol turnover in rat salivary glands. Mol Pharmacol 18:78-83.

Helke CJ, Krause JE, Mantyh PW, Couture R, Bannon MJ (1990) Diversity in mammalian tachykinin peptidergic neurons: multiple peptides, receptors, and regulatory mechanisms. FASEB J 4:16061615.

Henry JL (1976) Effects of substance $P$ on functionally identified units in cat spinal cord. Brain Res 114:439-451.

Henry JL (1983) Naloxone fails to block substance P-induced excitation of spinal nociceptive units. Brain Res Bull 10:727-730.

Hershey AD, Krause JE (1990) Molecular characterization of a functional cDNA encoding the rat substance $P$ receptor. Science 247:958962.

Hershey AD, Dykema PE, Krause JE (1991) Organization, structure, and expression of the gene encoding the rat substance $P$ receptor. $J$ Biol Chem 266:4366-4374.

Hokfelt T, Kellerth JO, Nilsson G, Pernow B (1975) Experimental immunohistochemical studies on the location and distribution of substance $P$ in cat primary sensory neurons. Brain Res 100:235-252.

Hunter JC, Goedert M, Pinnock RD (1985) Mammalian tachykinininduced hydrolysis of inositol phospholipids in rat brain slices. Biochem Biophys Res Commun 127:616-622.

Hylden JLK, Wilcox GL (1983a) Intrathecal opioids block a spinal action of substance $P$ in mice: functional importance of both $\mu$ - and $\delta$-receptors. Eur J Pharmacol 86:95-98.

Hylden JLK, Wilcox GL (1983b) Pharmacological characterization of substance $\mathrm{P}$ induced nociception in mice: modulation by opioid and noradrenergic agonists at the spinal level. J Pharmacol Exp Ther 226: 398-404.

Iadarola MJ, Brady LS, Draisci G, Dubner R (1988a) Enhancement of dynorphin gene expression in spinal cord following experimental inflammation: stimulus specificity, behavioral parameters and opioid receptor binding. Pain 35:313-326.

Iadarola MJ, Douglass J, Civelli O, Naranjo JR (1988b) Differential activation of spinal cord dynorphin and enkephalin neurons during hyperalgesia: evidence using cDNA hybridization. Brain Res 455: 205-212.

Ihara H, Nakanishi S (1990) Selective inhibition of expression of the substance $P$ receptor $m R N A$ in pancreatic acinar AR42J cells by glucocorticoids. J Biol Chem 265:22441-22445.

Jessell T, Tsunoo A, Kanazawa I, Otsuka M (1979) Substance P. depletion in the dorsal horn of rat spinal cord after section of the peripheral processes of primary sensory neurons. Brain Res 168:247259. 
Kantner RM, Kirby ML, Goldstein BD (1985) Increase in substance $P$ in the dorsal horn during a chemogenic nociceptive stimulus. Brain Res 338:196-199.

Kishimoto $\Lambda$, Takai Y, Mori T, Kikkawa U, Nishizuka Y (1980) Activation of calcium and phospholipid-dependent protein kinase by diacylglycerol, its possible relation to phosphatidylinositol turnover. J Biol Chem 255:2273-2276.

Krause JE, Chirgwin JM, Carter MS, Xu ZS, Hershey AD (1987) Three rat preprotachykinin mRNAs encode the neuropeptides substance $P$ and neurokinin A. Proc Natl Acad Sci USA 84:881-885.

Krause JE, Cremins JD, Carter MS, Brown ER, MacDonald MR (1989) Solution hybridization-nuclease protection assays for sensitive detection of differentially spliced substance P- and neurokinin A-encoding messenger ribonucleic acids. Methods Enzymol 168:634-652.

Krause JF, Sachais BS, Blount P (1993) Tachykinin receptors. In: Handbook of receptors and channels: G-protein coupled receptors (Peroutka SJ, ed), in press. Boca Raton, FL: CRC.

Kuraishi Y, Hirota N, Sugimoto M, Satoh M, Takagi H (1983) Effects of morphine on noxious stimuli-induced release of substance $P$ from rabbit dorsal horn in vivo. Life Sci 33[Suppl1]:693-696.

Kuraishi Y, Hirota N, Sato Y, Hino Y, Satoh M, Takagi H (1985) Evidence that substance $P$ and somatostatin transmit separate information related to pain in the spinal dorsal horn. Brain Res 325:294298.

Laneuville O, Dorais J, Couture R (1988) Characterization of the effects produced by neurokinins and three agonists selective for neurokinin receptor subtypes in a spinal nociceptive reflex of the rat. Life Sci 42:1295-1305.

Mantyh PW, Pinnock RD, Downes CP, Goedert M, Hunt SP (1984) Correlation between inositol phospholipid hydrolysis and substance $P$ receptors in rat CNS. Nature 309:795-797.

Mantyh PW, Gates T, Mantyh CR, Maggio JE (1989) Autoradiographic localization and characterization of tachykinin receptor binding sites in the rat brain and peripheral tissues. J Neurosci 9:258279.

Matsumura H, Sakurada T, Hara A, Sakurada S, Kisara K (1985) Characterization of the hyperalgesic effect induced by intrathecal injection of substance P. Neuropharmacology 24:421-426.

McCarson KE, Goldstein BD (1989) Naloxone blocks the formalininduced increase of substance $P$ in the dorsal horn. Pain 38:339-345.

McCarson KE, Goldstein BD (1990) Timecourse of the alteration in substance $P$ levels in the dorsal horn formalin: blockade by naloxone. Pain 41:95-100.

McCarson KE, Goldstein BD (1991) Release of substance P into the superficial dorsal horn following nociceptive activation of the hindpaw of the rat. Brain Res 568:105-116.

Minami M, Kuraishi Y, Kawamura M, Yamaguchi T, Masu Y, Nakanishi S, Satoh M (1989) Enhancement of preprotachykinin A gene expression by adjuvant-induced inflammation in the rat spinal cord: possible involvement of substance P-containing spinal neurons in nociception. Neurosci Lett 98:105-110.

Moussaoui SM, Hermans E, Mathieu AM, Bonici B, Clerc F, Guinet F, Garret C, Laudron PM (1992) Polyclonal antibodies against the rat NK1 receptor: characterization and localization in the spinal cord. Mol Neurosci Neuroreport 3:1073-1076.

Nakanishi S (1991) Mammalian tachykinin receptors. Annu Rev Neurosci 14:123-136.

Noguchi K, Ruda MA (1992) Gene regulation in an ascending nociceptive pathway: inflammation-induced increase in preprotachykinin mRNA in rat lamina I spinal projection neurons. J Neurosci 12:25632572.

Noguchi K, Morita Y, Kiyama H, Ono K, Tohyama M (1988) A noxious stimulus induces the preprotachykinin- $\Lambda$ gene expression in the rat dorsal root ganglion: a quantitative study using in situ hybridization histochemistry. Mol Brain Res 4:31-35.
Nudel U, Zaku R, Shani M, Neuman S, Levy Z, Yaffe D (1983) The nucleotide sequence of the rat cytoplasmic $\beta$-actin gene. Nucleic Acids Res 11:1759-1771.

Ogawa T, Kanazawa I, Kimura S (1985) Regional distribution of substance $\mathrm{P}$, neurokinin $\mathrm{A}$ and neurokinin $\mathrm{B}$ in rat spinal cord, nerve roots and dorsal root ganglia, and the effects of dorsal root section or spinal transection. Brain Res 359:152-157.

Oku R, Satoh M, Takagi H (1987) Release of substance P from the spinal dorsal horn is enhanced in polyarthritic rats. Neurosci Lett 74: 315-319.

Otsuka M, Yanagisawa M (1987) Does substance $\mathrm{P}$ act as pain transmitter? Trends Pharmacol Sci 8:506-510.

Pernow B (1983) Substance P. Pharmacol Rev 35:85-141.

Piercey MF, Dobry PJK, Schroeder LA, Einspahr FJ (1981) Behavioral evidence that substance $\mathrm{P}$ may be a spinal cord sensory neurotransmitter. Brain Res 210:407-412.

Radhakrishnan V, Henry JL (1991) Novel substance P antagonist, CP-96,345, blocks responses of cat spinal neurons to noxious cutaneous stimulation and to substance P. Neurosci Lett 132:39-43.

Salter MW, Henry JL (1991) Responses of functionally identified neurones in the dorsal horn of the cat spinal cord to substance $P$, neurokinin A, and physalaemin. Neuroscience 43:601-610.

Sanger F, Nicklen S, Coulson AR (1977) DNA sequencing with chainterminating inhibitors. Proc Natl Acad Sci USA 74:5463-5467.

Shigemoto R, Yokota Y, Tsuchida K, Nakanishi S (1990) Cloning and expression of a rat neuromedin $\mathrm{K}$ receptor cDNA. J Biol Chem 265:623-628.

Skilling SR, Smullin DH, Beitz AJ, Larson AA (1988) Extracellular amino acid concentrations in the dorsal spinal cord of freely moving rats following veratridine and nociceptive stimulation. J Neurochem 51:127-132.

Streb H, Irvine RF, Rerridge MJ, Schulz I (1983) Release of $\mathrm{Ca}^{2+}$ from a nonmitochondrial intracellular store in pancreatic acinar cells by inositol-1,4,5-trisphosphate. Nature 306:67-69.

Tjolsen A, Berge O-G, Hunskaar S, Rosland JH, Hole K (1992) The formalin test: an evaluation of the method. Pain 51:5-17.

Tsuchida K, Shigemoto R, Yokota Y, Nakanishi S (1990) Tissue distribution and quantitation of the mRNAs for three rat tachykinin receptors. Eur J Biochem 193:751-757.

Warden MK, Young WS (1988) Distribution of cells containing mRNAs encoding substance $\mathrm{P}$ and neurokinin $\mathrm{B}$ in the rat central nervous system. J Comp Neurol 272:90-113.

Yaksh TL, Elde RP (1991) Factors governing the release of methionine enkephalin-like immunoreactivity from mesencephalon and spinal cord of the cat in vivo. J Neurophysiol 46:1056-1075.

Yaksh TL, Jessell TM, Gamse R, Mudge AW, I eeman SE (1980) Intrathecal morphine inhibits substance $P$ release from mammalian spinal cord in vivo. Nature 286:455-457.

Yamamoto Y, Yaksh TL (1991) Stereospecific effects of a nonpeptidic NK1 selective antagonist, CP-96,345: antinociception in the absence of motor dysfunction. Life Sci 49:1955-1963.

Yashpal K, Dam TV, Quirion R (1990) Quantitative autoradiographic distribution of multiple neurokinin binding sites in rat spinal cord. Brain Res 506:259-266.

Yashpal K, Dam TV, Quirion K (1991) Effects of dorsal rhizotomy on neurokinin receptor sub-types in the rat spinal cord: a quantitative autoradiography study. Brain Res 552:240-247.

Yashpal K, Radhakrishnan V, Coderre TJ, Henry JL (1993) CP-96,345, but not its stereoisomer, CP-96-344, blocks the nociceptive responses to intrathecally administered substance $P$ and to noxious thermal and chemical stimuli in the rat. Neuroscience 52:1039-1047.

Yokota Y, Sasai Y, Tanaka K, Fujiwara T, Tsuchida K, Shigemoto R, Kakizuka A, Ohkubo H, Nakanishi S (1989) Molecular characterization of a functional cDNA for rat substance $\mathrm{P}$ receptor. $\mathrm{J}$ Biol Chem 264:17649-17652. 